\title{
EDUKACJA NA RZECZ ZRÓW NOWAŻONEGO ROZWOJU ZADANIEM SZKOLNICTWA WYŻSZEGO
}

Streszczenie: Zrównoważony rozwój jest aktualnie istotnym wyzwaniem w kształtowaniu świadomości nie tylko danych grup społecznych, lecz również - w szerszym rozumieniu - ogółu obywateli. Podejmując tę problematykę, należy zwrócić szczególną uwagę na rolę edukacji wszystkich etapów kształcenia w propagowaniu idei odpowiedzialności za środowisko naturalne i tym samym ekorozwoju. Szczególnie ważne w kształceniu w myśl zasad edukacji prośrodowiskowej jest podjęcie w placówkach szkolnych wszelkich działań, których celem jest stymulowanie świadomości środowiskowej młodzieży, a także przygotowanie kadry pedagogicznej do wdrażania szeregu metod i strategii pozwalających na uzyskanie jak najlepszych wyników w procesie edukacji młodego pokolenia.

Słowa kluczowe: świadomość środowiskowa, kształcenie środowiskowe, edukacja środowiskowa, zainteresowania przyrodnicze, postawy, poglądy proekologiczne, świadomość ekologiczna, szkolnictwo wyższe

\section{Wstęp}

Zmiany i przeobrażenia, jakie zaszły w polskiej szkole wyższej, zarówno treściowe, programowe, jak i strukturalne, stworzyły dogodną sytuację do propagowania założeń zrównoważonego rozwoju, ukierunkowanego na kształtowanie świadomości ekologicznej wśród studentów na wszystkich kierunkach studiów. Takie działania powinny mieć odzwierciedlenie w uzyskiwanych mierzalnych efektach dydaktycznych, a przede wszystkim w podejmowanych racjonalizatorskich przedsięwzięciach na rzecz środowiska.

Obecnie można zaobserwować dużą elastyczność systemu szkolnego, a przede wszystkim otwartość na nowe pomysły dydaktyczne i wychowawcze. Wdrażając zmiany, dąży się do przygotowania młodych ludzi do świadomego podejmowania nowych wyzwań. Wymaga to podniesienia skuteczności edukacji na uczelniach oraz lepszego niż dotychczas przygotowania nowego pokolenia do współistnienia 
ze środowiskiem. Natomiast dalsze permanentne doskonalenie $\mathrm{w}$ tym zakresie podniesie, uzupełni i uaktualni kwalifikacje oraz umożliwi nabycie nowych umiejętności, co umocni pozycję zawodową i zapewni stabilizację, będzie także sprzyjało autorefleksji, ciągłemu samodoskonaleniu i samorealizacji w wybranym zawodzie.

\section{Tradycyjne i nowe zadania szkolnictwa wyższego}

Obecnie na świecie zasoby kognitywne są czynnikiem rozwoju i będą w coraz większym stopniu wypierać zasoby materialne. Dlatego znaczenie potencjału intelektualnego szkolnictwa wyższego jako wartości będzie stale wzrastało. Co więcej, na skutek innowacji i permanentnego postępu technologicznego gospodarka będzie coraz częściej wymagała konkretnych kompetencji zawodowych młodych ludzi, uzyskiwanych na wysokim poziomie podczas studiów.

Te priorytetowe wyzwania to nowe zadania, z jakimi muszą zmierzyć się szkoły wyższe. Dlatego program realizowany w ramach kierunku studiów powinien zawierać solidną wiedzę podstawową, aby zapewnić wysoki ogólny poziom intelektualny absolwenta, oraz być dostatecznie szeroki, żeby dawać mu szansę skutecznej samorealizacji podczas wyboru różnorodnych dróg zawodowych. W związku z tym współczesna edukacja na poziomie szkolnictwa wyższego nie może istnieć bez edukacji środowiskowej i prozdrowotnej - potrzebnej, a nawet niezbędnej w procesie dydaktyczno-wychowawczym na każdym etapie, również na poziomie uniwersyteckim. Ma ona przygotowywać do przestrzegania i wdrażania zasad zrównoważonego rozwoju.

Jak twierdzi Wincenty Okoń (1997, s. 387), „szkoła wyższa to instytucja naukowo-wychowawcza, kształcąca młodzież i dorosłych na poziomie pomaturalnym, umożliwiająca ukończenie studiów wyższych i zdobycie stopni naukowych oraz prowadząca badania naukowe".

A edukacja na rzecz zrównoważonego rozwoju jest jednym z istotnych wyzwań współczesnej szkoły na wszystkich poziomach edukacyjnych, również na szczeblu szkolnictwa wyższego.

Zdaniem Danuty Cichy „w ostatnich latach obserwuje się wzrost świadomości ekologicznej wśród całego polskiego społeczeństwa. Uwarunkowane jest to przede wszystkim wieloma międzynarodowymi zobowiązaniami naszego kraju, a także pogarszającym się stanem środowiska. Większość zadań podejmowanych w edukacji wiąże się z przeprowadzoną ostatnio reformą szkolną i zbliżeniem polskiego systemu oświatowego do systemów istniejących w krajach wysoko rozwiniętych. Ważnym argumentem do podnoszenia efektywności kształcenia jest przygotowanie społeczeństwa do wcielenia trwałego i zrównoważonego rozwoju społeczno-gospodarczego w praktyczne działania w codziennym życiu. Kluczowym problemem we wprowadzeniu ekorozwoju jest świadomość środowiskowa ludzi dorosłych. Dlatego należy zapoznać studentów - często przyszłych decydentów - z dokumentem 
Agenda 21, który stanowi globalny program działań ukierunkowujących wdrażanie systemu wartości ekorozwoju i jego wpływu na zmiany" (Cichy 1998, s. 7).

W raporcie Międzynarodowej Komisji do spraw Edukacji dla XXI wieku pod przewodnictwem Jacques'a Delorsa pt. Edukacja - jest w niej ukryty skarb, opracowanym dla UNESCO, czytamy, że „w obliczu rozlicznych wyzwań edukacja jawi się jako szansa, którą należy bezwzględnie wykorzystać w dążeniu ludzkości do ideałów pokoju, wolności i sprawiedliwości społecznej" (Edukacja... 1998). Dlatego w zakresie kształcenia ogólnego na każdym etapie wszystkie grupy naszego społeczeństwa powinny być objęte edukacją ekologiczną, której oferta opracowywana będzie zarówno przez placówki oświatowe, jak też w ramach edukacji nieformalnej.

Prawidłowo prowadzona edukacja w tym zakresie powinna przynieść efekty w przyszłości, w postaci nawyków i postaw przyjaznych środowisku, i przyczynić się do popularyzacji tych treści w szerszych kręgach naszego społeczeństwa.

Edukacja na rzecz zrównoważonego rozwoju na poziomie akademickim uwzględnia:

- szkolnictwo zawodowe przygotowujące specjalistów do pracy w zawodach w zakresie ochrony środowiska,

- różnorodne formy doskonalenia zawodowego,

- popularyzację nowych osiągnięć naukowych,

- nauczanie mające na celu wdrożenie w problematykę środowiskową absolwentów szkół wyższych,

- studia podyplomowe dopełniające wiedzę z zakresu ochrony środowiska,

- studia doktoranckie,

- inicjowanie i rozwijanie ruchów studenckich oraz kół naukowych,

- organizację kongresów, konferencji, seminariów, sympozjów naukowych i innych form działalności na rzecz zrównoważonego rozwoju i edukacji w tym zakresie,

- aktywne uczestnictwo w programach krajowych i międzynarodowych.

Uczelnie prowadzą kierunki studiów związane z ochroną środowiska albo uwzględniają w programach autorskich edukację ekologiczną, a także potrzeby kształceniowe środowisk lokalnych, współdziałając $\mathrm{w}$ tym zakresie $\mathrm{z}$ administracją rządową i samorządową oraz z ośrodkami i ruchami ekologicznymi.

Obecnie w szkole można zaobserwować istotną zmianę, polegającą na przejściu w wymaganiach programowych od wyników nauczania do kompetencji ucznia. Aktualnie zdaniem Andrzeja Bogaja „wymaga się, by były to: kompetencje cywilizacyjne (a wśród nich ekologiczne), kompetencje związane $\mathrm{z}$ wychowaniem do wartości, kompetencje związane z etosem pracy, kompetencje związane z etosem nauki, kompetencje związane z komunikacją interpersonalną" (Bogaj 200o, s. 78). $\mathrm{W}$ ostatnich latach wzrasta również zainteresowanie osób dorosłych zdobywaniem wiedzy w nieobligatoryjnym systemie nauczania.

Współczesny rozkwit i rozwój cywilizacji bez wątpienia ułatwiają codzienne życie. Zmniejszają również w znacznym stopniu uzależnienie człowieka od przyrody. Jednocześnie wymagają, by korzystać z nowoczesnych wytworów techniki, 
i egzekwują od producentów dóbr konsumpcyjnych wprowadzanie dalszych udoskonaleń. A to w konsekwencji pociąga za sobą nieuchronne naruszenie równowagi przyrodniczej i bioróżnorodności biologicznej. Jest również przyczyną globalnych zmian klimatycznych, efektu cieplarnianego, rozrzedzenia warstwy ozonowej i zanieczyszczeń gleby, powietrza oraz wody. „Edukacja w tym zakresie nie zmieni od razu tych tendencji, ale ukształtuje świadomość o ścisłej zależności człowieka od przyrody. Jej zadaniem jest również wprowadzenie młodzieży w świat niezwykłych przeżyć emocjonalnych i estetycznych związanych z przebywaniem w środowisku oraz wykształcenie umiejętności świadomego włączania się w dzieło ochrony i kształtowania środowiska" (Kąkol 2002, s. 46).

Zasadniczym celem edukacji środowiskowej we współczesnej szkole jest „kształtowanie wysokiego poziomu świadomości, czyli odpowiedzialnej postawy człowieka wobec środowiska. Szkoła powinna odpowiednio przygotować uczniów do podejmowania racjonalnych działań służących ochronie przyrody, poprawie stanu środowiska, dostrzeganiu zagrożeń cywilizacyjnych oraz rozwiązywaniu problemów związanych z ochroną i degradacją środowiska w najbliższym otoczeniu. Zadaniem szkoły jest umożliwienie wszystkim kształcącym się poznanie podstawowych praw przyrody oraz norm prawidłowego funkcjonowania w środowisku" (Cichy 2002, s. 20).

\section{Innowacyjność w procesie dydaktycznym w szkolnictwie wyższym}

Szkolnictwo wyższe powinno pełnić określone funkcje dla społeczeństwa w ramach realizacji założeń zrównoważonego rozwoju, takie jak:

- inicjowanie rozwoju gospodarczego,

- opracowywanie i wdrażanie innowacyjnych technologii produkcyjnych przyjaznych środowisku,

- prowadzenie prac badawczych w zakresie ochrony środowiska,

- monitorowanie stanu środowiska,

- kreowanie wiedzy,

- upowszechnianie osiągnięć naukowych.

Aktywność poznawcza oznacza działanie nastawione na zdobywanie wiedzy, a aktywność emocjonalna umożliwia poznanie wartości. Jedność wiedzy i wartości staje się zaś zasadą działań kształtujących człowieka. Oprócz wiedzy i wartości istotne są również konkretne umiejętności, za sprawą których urzeczywistnia się to, co dla człowieka jest cenne. Znamienną właściwością działania pedagogicznego jest zatem jego złożoność, niestandardowość.

Dlatego standardy nauczania dla poszczególnych kierunków powinny być dostatecznie pojemne, aby umożliwić różnorodne, zależne od specyfiki uczelni i oczekiwań studentów realizacje programowe, przy zapewnieniu indywidualizacji procesu kształcenia studenta i mobilności podczas studiów. Duże możliwości w tym zakresie dają prowadzone w ramach kierunku studiów specjalizacje i specjalności. 
Edukacja na rzecz zrównoważonego rozwoju na szczeblu szkolnictwa wyższego „pozwala poznać i zrozumieć relacje z otaczającym nas światem, wyjaśnić procesy w nim zachodzące, a także nauczyć prawidłowego funkcjonowania. Ideą tej edukacji jest dążenie do osiągnięcia równowagi pomiędzy społecznym i ekonomicznym dobrem oraz kulturą, tradycją i ochroną zasobów naturalnych. Edukacja na rzecz zrównoważonego rozwoju podkreśla potrzebę respektowania godności ludzkiej, poszanowania różnorodności, ochrony środowiska naturalnego i zasobów naszej planety. Ideałem, do którego należy dążyć, jest zapewnienie każdej jednostce możliwości kształcenia zgodnego $\mathrm{z}$ jej zdolnościami oraz wpajanie $\mathrm{w}$ procesie kształcenia wartości, bez których niemożliwy byłby zrównoważony rozwój społeczny. Warunkiem koniecznym do spełnienia jest nieustanny monitoring jakości procesu i efektów kształcenia" (Bielska 2006, s. 25).

Obecnie edukacja jest ważną inwestycją społeczną, gospodarczą i polityczną. Dlatego „wykształcenie i kompetencje ludzi stają się najważniejszą wartością współczesnej informacyjnej cywilizacji oraz społeczeństw opartych na wiedzy. Reforma systemu edukacji w Polsce jest więc priorytetowym i trudnym zadaniem, ściśle związanym z wyzwaniami globalizacji świata, transformacji systemowej (ustrojowej) oraz procesami integracji europejskiej" (Banach 2000, s. 9).

Edukacja dorosłych ma swoją specyfikę, gdyż dorosłość charakteryzuje się osiągnięciem zdolności spostrzegania i analizy sytuacji otaczających jednostkę, podejmowania decyzji oraz brania odpowiedzialności za dokonywane wybory. „Szczególnie należy upowszechniać wśród ludzi dorosłych wszystkie ważne odkrycia naukowe, które zmuszają do zmiany dotychczasowych poglądów. Bardzo ważne, aby informacje były zrozumiałe dla odbiorców i przydatne w życiu codziennym, np. dla zachowania zdrowia fizycznego i psychicznego" (Cichy 1998, s. 45).

Wiele podejmowanych przedsięwzięć edukacyjnych nie wpływa w sposób satysfakcjonujący na wzrost świadomość środowiskowej „przeciętnego" Polaka, która nadal jest niezadowalająca. Pojęcie ekologii kojarzy się najczęściej z popularnymi reklamami handlowymi, mającymi niewiele wspólnego z ochroną środowiska i zrównoważonym rozwojem. Dlatego wciąż należy poszukiwać nowych, innowacyjnych form i metod edukacyjnych oraz wykorzystywać tradycyjne, które przynoszą wymierne efekty. Edukacja prośrodowiskowa powinna stać się priorytetowym elementem wykształcenia współczesnego człowieka.

Zdaniem Stefana Kozłowskiego ,jeżeli chcemy dokonać zwrotu i realizować założenia zrównoważonego rozwoju, to konieczna jest zmiana światopoglądu i sposobu myślenia. Jest to możliwe poprzez systematyczne uczenie młodego pokolenia myślenia holistycznego, globalnego i ekologicznego. Potrzebny jest globalny zbiorowy wysiłek intelektualny, mający wytyczyć dalsze drogi i sposoby życia na ziemi" (Kozłowski 1998, s. 27)

Warto podjąć odpowiednie kroki w każdej sferze ludzkiej działalności: ekonomicznej, prawnej i gospodarczej, aby zmienić światopogląd wszystkich grup społecznych i przygotować przyszłe pokolenia do wdrażania zasad zrównoważonego 
działania oraz ukształtowania odpowiedniej kultury ekologicznej. Efektywność tego procesu może być zapewniona przez kompleksowe czynności prowadzone w edukacji formalnej i nieformalnej.

Edukacja środowiskowa jest więc potrzebna, a nawet niezbędna we współczesnym procesie dydaktyczno-wychowawczym na każdym etapie szkolnictwa, również uniwersyteckim obejmującym przyszłą inteligencję, bo przygotowuje do przestrzegania i wdrażania zasad zrównoważonego rozwoju.

Elementarna wiedza z zakresu zrównoważonego rozwoju jest niezbędną częścią wykształcenia ludzi pracujących w każdym zawodzie, ponieważ realizacja założeń ekorozwoju wymaga wysokiej społecznej świadomości. Dlatego w procesie kształcenia i wychowania przyszłych obywateli należy uwzględnić i wyeksponować tę problematykę poprzez realizację różnych przedsięwzięć pedagogicznych.

„Zasadniczym celem edukacji środowiskowej we współczesnej szkole jest kształtowanie wysokiego poziomu świadomości, czyli odpowiedzialnej postawy człowieka wobec środowiska. Szkoła powinna odpowiednio przygotować do podejmowania uzasadnionych działań służących ochronie przyrody, poprawie stanu środowiska, dostrzeganiu zagrożeń cywilizacyjnych oraz rozwiązywaniu problemów związanych z ochroną i degradacją środowiska w najbliższym otoczeniu. Zadaniem edukacji jest umożliwienie wszystkim kształcącym się poznanie podstawowych praw przyrody oraz zasad prawidłowego funkcjonowania w środowisku" (Cichy 2002, s. 19).

Nauczanie i uczenie się w szkołach wyższych uwzględniające zrównoważony rozwój powinno polegać na:

- kształceniu mającym na celu wprowadzenie w problematykę środowiskową absolwentów wszystkich szkół wyższych,

- wprowadzaniu zróżnicowanego zakresu tego kształcenia i jego form,

- obligatoryjnym wprowadzeniu edukacji z tego zakresu,

- przygotowywaniu specjalistów do pracy zawodowej w zakresie ochrony środowiska,

- organizowaniu studiów podyplomowych uzupełniających wiedzę z ochrony środowiska,

- wdrażaniu nieformalnej edukacji ekologicznej poprzez otwarte uniwersytety i wykłady.

Do realizacji powyższych celów niezbędne są następujące działania:

1. przekazywanie podstawowej wiedzy z zakresu nauk:

- przyrodniczych,

- ekonomiczno-technicznych,

- humanistycznych,

2. kształtowanie postaw przyjaznych środowisku.

$\mathrm{W}$ dalszym ciągu mało jest przedmiotów na różnych kierunkach studiów dostarczających kompleksowej wiedzy z tego zakresu oraz informacji na temat kontekstów społecznych, a także pogłębiających znajomość technologii oraz technik 
stosowanych w ochronie środowiska. W konsekwencji część absolwentów jest dobrze zorientowana w zagadnieniach przyrodniczych i realiach ochrony środowiska, ale nie rozumie prawidłowości uwarunkowań technicznych, społecznych i ekonomicznych. Prowadzi to niekiedy do zajmowania ekstremalnych postaw, w imię tej ochrony negujących wręcz potrzebę rozwoju gospodarczego. $Z$ drugiej strony absolwenci przygotowani do stosowania techniki w ochronie środowiska nie doceniają uwarunkowań przyrodniczych i społecznych. Kompleksowe studia są niezbędne w celu podnoszenia ogólnego poziomu intelektualnego.

Uczelnie powinny:

- organizować studia podyplomowe, kursy, nie tylko dla nauczycieli, ale również dla pracowników administracji, dziennikarzy, a także dla innych osób odpowiedzialnych za podejmowane decyzje w środowisku lokalnym i zainteresowanych problematyką środowiskową,

- opracowywać, publikować oraz promować podręczniki i skrypty dotyczące problematyki ochrony środowiska $\mathrm{z}$ eksponowaniem rozwoju postrzeganego $\mathrm{w}$ kategoriach społecznych, ekonomicznych i kulturowych.

Niekwestionowanym priorytetem uczelni i innych instytucji naukowych powinna być popularyzacja wiedzy środowiskowej.

System kształcenia formalnego w Polsce trzeba zmodyfikować pod względem jakości i dostosować do wymagań gospodarki opartej na wiedzy. Przede wszystkim należy zapewnić powiązanie pomiędzy uczelniami, społecznością akademicką a biznesem, co sprzyja procesowi transferu najnowszych technologii. Udział szkół wyższych w kształtowaniu edukacji ekologicznej należy uznać za bardzo ważną część systemu nauczania. Proces zmian powinien odnosić się do rzeczywistej sytuacji występującej w kraju. Wymaga to wprowadzenia innowacyjnych praktycznych doświadczeń, np. w zakresie zarządzania środowiskowego, interdyscyplinarnych koncepcji kształcenia i kwalifikacji przyszłej kadry zarządzającej.

„Powodzenie pracy popularyzatorskiej w zakresie ochrony środowiska zależy w znacznym stopniu od nawiązywania kontaktu z jak największą grupą dorosłych (nauczycieli, rodziców, konsumentów, producentów, polityków, urzędników, naukowców itp.), dostosowania formy przekazu wiedzy ekologicznej do jak najszerszego grona odbiorców oraz wytworzenia wewnętrznej motywacji związanej z ochroną przyrody" (Stawiński 1998, s. 205).

Skuteczność tych działań jest możliwa dzięki włączeniu problematyki środowiskowej do życia społecznego na wszystkich poziomach - od nauczania, tworzenia nauki przez politykę, administrację, planowanie do budownictwa, działalności gospodarczej, a także codziennego stylu życia pojedynczego obywatela oraz dużych grup społecznych.

Grzegorz Embros twierdzi, że ,jednym z istotnych zadań szkoły współczesnej jest wyposażenie jej podopiecznych w sprawności, umożliwiające właściwą egzystencję w środowisku społecznym. Coraz częściej akcentuje się również, w związku z sytuacją kryzysu ekologicznego, umiejętność kształtowania odpowiednich relacji 
pomiędzy społeczeństwem a przyrodą. Coraz większy nacisk kładzie się na zdobywanie kompetencji w zakresie rozwiązywania problemów i podejmowania decyzji. W kontekście procesów decyzyjnych nie można uniknąć kwestii odpowiedzialności i motywacji" (Embros 2010, s. 159).

Dlatego bardzo ważną inicjatywą jest również permanentne doskonalenie zawodowe, interpretowane jest ono jako „proces systematycznego aktualizowania, poszerzania oraz pogłębiania wiadomości i umiejętności, a także sprawności ogólnych i zawodowych. Jest to więc proces ściśle związany z wykonywanym zawodem oraz z zawodami pokrewnymi, umożliwiającymi stopniowe dochodzenie do mistrzostwa w zawodzie oraz uzyskiwanie coraz wyższej pozycji społeczno-zawodowej bez konieczności wychodzenia z zawodu" (Wiatrowski 1994, s. 486), np. poprzez specjalizacje lekarskie, inżynierskie, nauczycielskie itp.

Przedsięwzięciem godnym naśladowania było uruchomienie studiów podyplomowych w ramach realizacji projektu „Poradnictwo zawodowe otwarte na kształtowanie świadomości ekologicznej społeczeństwa" (fundusze norweskie) przez Wydział Nauk Pedagogicznych Uniwersytetu Kardynała Stefana Wyszyńskiego w Warszawie pod kierunkiem naukowym dr hab. Barbary Baraniak, prof. UKSW, oraz prof. zw. dr hab. Danuty Cichy. Ta nowatorska koncepcja poszerzania wiedzy doradców zawodowych o zagadnienia z zakresu ochrony środowiska, problematyki dotychczas niedocenianej w poradzie zawodowej, cieszyła się dużym zainteresowaniem. Studia wpisały się w jeden z priorytetów, objętych siódmym obszarem "Ochrony środowiska”, nakładających obowiązek przyjęcia norm ekologicznych obowiązujących w krajach UE, a ponadto przekładających się na potrzebę dostosowania i wprowadzenia istotnych zmian technologicznych we wszystkich zakładach produkcyjnych w zakresie ograniczenia uciążliwych dla środowiska naturalnego odpadów, emisji spalin, ścieków itp. Tematyka ta wkomponowała się w nowe obszary kształcenia doradców zawodowych, którymi są problemy ochrony środowiska. W ramach zrealizowanego projektu wyposażono doradców zawodowych w wiedzę ekologiczną i umiejętności kształtowania postaw prośrodowiskowych oraz świadomość wartości podejmowanych ekologicznych działań edukacyjnych. W programie studiów były wykłady, ćwiczenia audytoryjne i terenowe oraz warsztaty. Część wyników prac studyjnych wykorzystano do opracowania monografii, składającej się z części teoretycznej i praktycznej.

Potrzeba ciągłego doskonalenia zawodowego wynika więc z rozwoju nauki i techniki.

\section{Podsumowanie}

„Objęcie permanentną edukacją całego społeczeństwa jest warunkiem wdrożenia zasad zrównoważonego rozwoju. Należy również dążyć do tego, aby edukacja przede wszystkim dorosłych nie ograniczała się wyłącznie do funkcji dydaktycznej, ale zdobyte $\mathrm{w}$ jej toku informacje znajdowały zastosowanie bezpośrednio 
w praktyce, w realizowanych inwestycjach proekologicznych" (Buchcic 1998, s. 205). Świadomość środowiskowa to bowiem nie tylko wiedza o środowisku, ale i umiejętność dostrzegania problemów wokół i reagowania na nie, czyli prezentowanie aktywnej postawy prośrodowiskowej, w której kształtowaniu niebagatelna rola przypada edukacji formalnej, jak również nieformalnej.

Podstawowym zadaniem i celem do osiągnięcia powinno być przyjęcie doktryny $\mathrm{z}$ raportu UNESCO pt. Edukacja - jest w niej ukryty skarb, w którym sformułowano cztery filary edukacji:

"- uczyć się, aby wiedzieć; tzn. aby zdobywać narzędzia rozumienia,

- uczyć się, aby działać [...],

- uczyć się, aby żyć wspólnie [...],

- uczyć się, aby być".

W społeczeństwie szkolnictwo wyższe jest i powinno być motorem rozwoju gospodarczego i jednym z biegunów edukacji przez całe życie, depozytariuszem oraz kreatorem wiedzy.

W świecie, w którym zasoby kognitywne jako czynniki rozwoju będą w coraz większym stopniu wypierać zasoby materialne, znaczenie szkolnictwa wyższego będzie stale wzrastało. Co więcej, na skutek innowacji i postępu technologicznego gospodarka coraz częściej będzie wymagała kompetencji zawodowych uzyskiwanych na wysokim poziomie podczas studiów. $Z$ tymi nowymi zadaniami muszą zmierzyć się szkoły wyższe.

\section{Bibliografia}

Banach C. (2000). Edukacja nauczycielska dla reformy i rozwoju edukacji w Polsce. W: Sałata E. (red.). Kompetencje zawodowe nauczycieli a problemy reformy edukacyjnej. Radom: Wydawnictwo i Zakład Poligrafii Instytutu Technologii Eksploatacji.

Bielska A. (2006). Rola Ministerstwa Środowiska w ksztattowaniu świadomości ekologicznej społeczeństwa. „Edukacja Biologiczna i Środowiskowa”, nr 3.

Bogaj A. (2000). Kształcenie ogólne. Między tradycją a ponowoczesnością. Warszawa: Instytut Badań Naukowych.

Buchcic E. (1998). Świadomość ekologiczna dorostych a uczestnictwo ich dzieci w zielonych szkołach. W: Cichy D. (red.). Kształcenie ekologiczne dorostych. Warszawa: Instytut Badań Naukowych.

Cichy D. (2002). Ewaluacja zmian w edukacji środowiskowej wprowadzonych reforma szkolna. „Zeszyty Naukowe PAN”, nr 31, s. 19.

Cichy D. (1998). Kształcenie dorosłych dla trwałego i zrównoważonego rozwoju. „Zeszyty Naukowe PAN”, nr 23, s. 45.

Edukacja - jest w niej ukryty skarb. Raport dla UNESCO, pod przewodnictwem J. Delorsa (1998), tłum. W. Rabczuk. Warszawa: Stowarzyszenie Oświatowców Polskich, s. 215. 
Embros G. (2010). Instrumenty wsparcia edukacji dla zrównoważonego rozwoju. „Studia Ecologiae et Bioethicae”, 8 (1), s. 159.

Kąkol J. (2002). Edukacja EKOlogiczna w szkole podstawowej. Warszawa: WSiP. Kozłowski S. (1998). Trwały zrównoważony rozwój - bariery i dylematy. W: Cichy D. (red.). Kształcenie ekologiczne dorostych. Warszawa: Instytut Badań Naukowych. Okoń W. (1997). Nowy słownik pedagogiczny. Warszawa: Państwowe Wydawnictwo Naukowe.

Stawiński W. (1998). Popularyzacja wiedzy ekologicznej wśród dorosłych. W: Cichy D. (red.). Kształcenie ekologiczne dorostych. Warszawa: Instytut Badań Naukowych. Wiatrowski Z. (1994). Podstawy pedagogiki pracy. Bydgoszcz: Wyższa Szkoła Pedagogiczna.

\section{EDUCATION FOR SUSTAINABLE DEVELOPMENT AS THE MISSION OF HIGHER EDUCATION}

Summary: Balanced development is at present a challenge for creating awareness not only of a particular society, but also in the widest sense a whole generation of people. When such issues are undertaken, the role of education during all stages of teaching should be taken into consideration, especially in the range of promoting the idea of responsibility for the natural environment and eco-development. It is a specially important element of teaching according to the principle of pro-environmental education to undertake all actions in the educational centers, which aim is to stimulate the environmental awareness of young people as well as to prepare the pedagogical staff in the implementation of the wide range of methods and strategies that allow to get the best results during the process of educating the young generation.

Keywords: environmental awareness, environmental education, scientific interests, basis, pro-ecological views, ecological awareness, higher education

Elżbieta Buchcic - doktor nauk humanistycznych w zakresie pedagogiki, adiunkt w Zakładzie Zoologii i Dydaktyki Biologii w Instytucie Biologii na Uniwersytecie Jana Kochanowskiego w Kielcach, wcześniej nauczyciel biologii, przyrody i biblioteczny, doradca metodyczny. Prowadzi badania dotyczące zrównoważonego rozwoju, przedsiębiorczości i doradztwa zawodowego oraz edukacji środowiskowej formalnej i nieformalnej w różnych grupach społecznych. Autorka bądź współautorka ponad 240 publikacji. Na uwagę zasługują: Zielone szkoły - działalność i możliwości podwyższania skuteczności edukacyjnej (2005) i napisane we współautorstwie: Nauczyciel przyrodnik. Zasoby, konteksty, działanie pedagogiczne (2011), Proces dydaktyczno-wychowawczy w edukacji biologicznej. Kompendium - nauczycielna starcie (2016). Adres e-mail: ebuchcic2@wp.pl. 